\title{
Low genetic diversity and intrapopulation spatial genetic structure of the Atlantic Forest tree, Esenbeckia leiocarpa Engl. (Rutaceae)
}

\author{
G. Forti, E.V. Tambarussi, P.Y. Kageyama, M.A. Moreno, E.M. Ferraz, B. Ibañes, G.M. \\ Mori, R. Vencovsky, A.M. Sebbenn
}

Forti G., Tambarussi E.V., Kageyama P.Y., Moreno M.A., Ferraz E.M., Ibañes B., Mori G.M., Vencovsky R., Sebbenn A.M. 2014. Low genetic diversity and intrapopulation spatial genetic structure of the Atlantic Forest tree, Esenbeckia leiocarpa Engl. (Rutaceae). Ann. For. Res. 57(2): 165-174, 2014.

Abstract. Studies on population genetics are the key to designing effective in situ management plans for tree species, in particular, those subjected to pressure from anthropogenic processes, such as forest fragmentation and logging. To investigate genetic diversity, inbreeding and intrapopulation spatial genetic structure (SGS) in a fragmented population of the insect-pollinated tropical tree, Esenbeckia leiocarpa, we developed specific microsatellite markers for this species and mapped and sampled 100 individuals in a forest plot. Two issues were addressed in particular: (i) the level of genetic diversity, inbreeding and effective population size, (ii) whether intrapopulation spatial genetic structure exists. Among the 14 loci developed, we only used the three that presented polymorphism to estimate the genetic parameters. Genetic diversity was low, whereby the average number of alleles per locus $(A)$ was 3.3 and observed $\left(H_{0}\right)$ and expected heterozygosities $\left(H_{e}\right)$ were 0.336 and 0.298 , respectively. The average fixation index was significantly higher than zero $(F=0.112)$, suggesting inbreeding. Significant SGS was found up to $7 \mathrm{~m}$ and between 31 to $38 \mathrm{~m}$, indicating that trees growing within these distances may be related. Estimates of the effective population size indicated that the 100 sampled trees correspond to 14 individuals that are neither related nor inbred. Our results suggest that the microsatellite markers developed in this study are suitable for studies on genetic diversity and structure, mating systems, gene flow and SGS in this species. Keywords Brazilian Atlantic forest, conservation genetics, microsatellite markers, population genetics, tropical tree species.

Authors. Giullia Forti - Universidade Metodista de Piracicaba - Unimep, Escola Superior de Agricultura "Luiz de Queiroz", University of São Paulo, Av. Padua Dias, 11, PO Box 9, Piracicaba, SP, 13418-900, Brazil; Evandro Vagner Tambarussi, Paulo Yoshio Kageyama, Maria Andreia Moreno, Elza Martins Ferraz, Bruna Ibañes, Roland Vencovsky - Escola Superior de Agricultura "Luiz de Queiroz", University of São Paulo, Av. Padua Dias, 11, PO Box 9, Piracicaba, SP, 13418-900, Brazil; Gustavo Maruyama Mori - Centro de Biologia Molecular e Engenharia Genética (CBMEG). AV Candido Rondon, 400 - Universidade 
de Campinas (Unicamp), Campinas - SP, 13083-875, Agência Paulista de Tecnologia dos Agronegócios, Pólo Regional Centro Sul, Rodovia SP127, Km 30, CP 28, Piracicaba, SP CEP13400-970, Brazil; Alexandre Magno Sebbenn (alexandresebbenn@yahoo.com.br.) - Instituto Florestal de São Paulo, CP 1322, São Paulo, SP, 01059-970.

Manuscript received May 17, 2014; revised September 12, 2014; accepted September 22, 2014; online first October 26, 2014.

\section{Introduction}

Due to extensive forest fragmentation worldwide, in and ex situ conservation plans for tree species are necessary to ensure that future generations continue to receive the same benefits (Sebbenn 2011). As tree species are key constituents of the forests due their large size and longevity, their conservation is of particular importance (Rajora \& Mosseler 2001). Within the forest fragmentation context, one of the global biomes with the most biodiversity, the Brazilian Atlantic Forest, has experienced high rates of deforestation and fragmentation, with less than $17 \%$ of the original forest cover remaining (Ribeiro et al. 2009). This biome is characterized by high levels of species endemism (Novaes 2001). Genetic conservation is especially important for endemic tree species, since forest fragmentation can lead to species extinction or loss of many tree populations. Forest fragmentation has detrimental effects, resulting in decreased population sizes, isolation of populations and reduced area for species regeneration (Bittencourt \& Sebbenn 2007, Sebbenn et al. 2011). This, in turn, decreases genetic diversity and increases inbreeding and intrapopulation spatial genetic structure (SGS), thus reducing the effective population size (Lowe et al. 2005, Aguilar et al. 2008, Sebbenn et al. 2011).

Esenbeckia leiocarpa Engl. is a climax species endemic to the Atlantic Forest in Brazil with a high density of individuals per population ( $>100$ trees/ha, Seoane et al. 2001). This species is used for various purposes, including civil construction, as a medicinal plant (treat- ment for Alzheimer's disease), and additionally has allelopathic effects that may be used in crop farming (Nakatsu et al. 1990, Sousa et al. 2010). E. leiocarpa flowers are hermaphroditic and pollination occurs by flies. Studies have shown the species to be self-incompatible, suggesting that mating only occurs through outcrossing (Faegri \& Pijl 1966). Seed dispersal is primarily by autochory and secondarily by birds (Seoane et al. 2000). Another earlier study by Seoane and colleagues (2001) reported mating among related individuals, suggesting that populations of E. leiocarpa present SGS and some levels of inbreeding.

Due to the significant reduction in the area of forest cover and high rates of fragmentation in the Brazilian Atlantic Forest, the remaining populations of E. leiocarpa are experiencing changes in the patterns of genetic diversity, inbreeding, effective population size, SGS and gene flow. Small and isolated populations with short-distance pollen and seed dispersal are expected to generate decreased genetic diversity and effective population size, along with increased inbreeding and SGS (White et al. 2002, Lowe et al. 2005, Bittencourt \& Sebbenn 2007, Sebbenn et al. 2011, Breed et al. 2013). Inbreeding leads to reductions in heterozygosity and reproductive vigor, with the main consequence being that homozygotes of deleterious recessive alleles become more frequent, compared to populations with random mating patterns.

Microsatellite markers, commonly used in plant population studies, provide new opportunities to understand ecological and genetic processes. Increased awareness of these proc- 
esses enables researchers to reduce the negative impacts of human activities on different tree species. Due to their high polymorphism in terms of number of alleles and high discriminatory power, microsatellite markers are suitable for examination of genetic diversity, inbreeding, effective population size, SGS and gene flow, and have become a popular tool in population and conservation genetics (Chase et al. 1996, Selkoe \& Toonen 2006). Markers developed for a specific species can additionally be used in analyses of related species (White \& Powell 1997). Comparative genetic studies have revealed that gene content and order are highly conserved among closely related plant species. Sequence data obtained from several plants indicate considerable homology in the regions flanking the microsatellite loci of two or more closely related genera/species (Kalia et al. 2011).

In the current study, we described the development of 14 nuclear microsatellite markers for a high-density population of E. leiocarpa within a forest fragment. Two issues in particular were explored: i) the level of genetic diversity, inbreeding and effective population size, and ii) spatial genetic structure within the population.

\section{Materials and methods}

\section{Sampling and study site}

We mapped, measured (diameter at breast height; DBH) and sampled leaves of $100 \mathrm{E}$. leiocarpa adult trees in a $50 \times 60 \mathrm{~m}$ plot established in the Ibicatu forest fragment $\left(22^{\circ} 46^{\prime}\right.$ $\mathrm{S}$ and $47^{\circ} 43^{\prime} \mathrm{W}$, average altitude of $542 \mathrm{~m}$ ), Piracicaba, São Paulo State, Brazil (Figure 1) with a total area of 72 ha. According to the Köppen classification system, the climate is Cwa with a mean temperature of $23.9^{\circ} \mathrm{C}$ in January (the hottest month) and $16.1^{\circ} \mathrm{C}$ in July (the coldest month). The Cwa climate is characterized as humid and mesothermal, with variations in the monthly mean temperature from
14.3 to $24.7^{\circ} \mathrm{C}$ (Köeppen 1948). This semi-deciduous forest remnant is currently surrounded by various types of land use, mainly agricultural (sugarcane, Eucalyptus) and pastural. The forest has been subjected to several fires and selective logging. Within the studied fragment, the population density of E. leiocarpa is 278 trees/ha with DBH ranging from 1.6 to $44.8 \mathrm{~cm}$ (average $\pm \mathrm{SD}=17.3 \pm 11.2 \mathrm{~cm}$, median $16.2 \mathrm{~cm})$.

\section{Development of microsatellite library and analysis}

Total genomic DNA was extracted from fresh leaves collected from a single tree of E. leiocarpa (Voucher: ESA-126337: Herbarium of the Universidade de São Paulo, São Paulo, Brazil, ESA) using the protocol of Doyle \& Doyle (1987). A microsatellite-enriched genomic library was constructed following the instructions of Billotte et al. (1999). AfaI (Invitrogen, Carlsbad, California, USA) was used to digest genomic DNA, and microsatellite enrichment performed based on $(\mathrm{CT})_{8}$ and $(\mathrm{GT})_{8}$ probes. Selected fragments were cloned into pGEM-T vectors (Promega, Madison, Wisconsin, USA) and the ligated products used to transform XL1-Blue Escherichia coli competent cells. Transformed cells were cultivated on agar plates containing $100 \mathrm{mg} / \mathrm{mL}$ ampicillin, $50 \mathrm{mg} / \mathrm{mL} \mathrm{X}$-galactosidase, and isopropyl $\beta$-D-1-thiogalactopyranoside (IPTG) for blue/ white screening, and single white colonies selected and stored at $-80^{\circ} \mathrm{C}$. In total, 96 recombinant colonies were sequenced on a 3730 xl DNA Analyzer sequencer (Applied Biosystems, Foster City, California, USA) using the BigDye Terminator v3.1 Cycle Sequencing Kit (Applied Biosystems). Sequencing reactions were performed using a solution of 10 $\mu \mathrm{L}$ autoclaved MilliQ water, $2 \mu \mathrm{L}$ Save Money buffer, $0.5 \mu \mathrm{L}$ T7 or SP6 primer $(0.5 \mathrm{mM}), 4$ $\mu \mathrm{L}$ plasmid for samples with highly concentrated DNA or $6 \mu \mathrm{L}$ for samples with less concentrated DNA, and $0.4 \mu \mathrm{L}$ Big Dye. Vector segments were removed from each sequence 


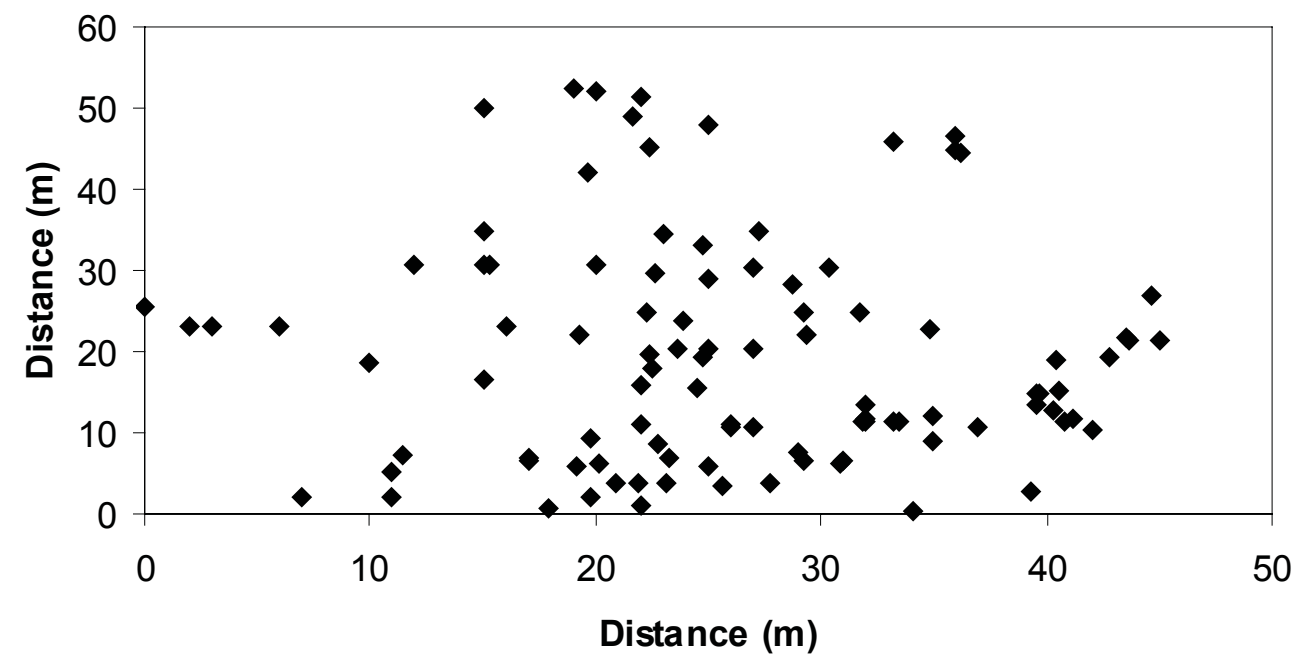

Figure 1 Spatial distribution of trees of Esenbeckia leiocarpa in the studied plot in Ibicatu, São Paulo State, Brazil

using VecScreen (http://www.ncbi.nlm.nih. gov/VecScreen) based on an annealing temperature range of $54-64^{\circ} \mathrm{C}$. Each primer pair was designed to amplify a fragment between 150 and $300 \mathrm{bp}$. The amplification program consisted of an initial denaturing step at $94^{\circ} \mathrm{C}$ for $1 \mathrm{~min}$, followed by 35 cycles of amplification $\left(94^{\circ} \mathrm{C}\right.$ for $1 \mathrm{~min}$, the specific annealing temperature of each primer pair for $1 \mathrm{~min}$ [Table $1], 72^{\circ} \mathrm{C}$ for $1 \mathrm{~min}$ ), and a final elongation step at $72^{\circ} \mathrm{C}$ for $10 \mathrm{~min}$. Amplifications were performed in a Mastercycler thermocycler (Eppendorf, Hamburg, Germany). Fourteen pairs of primers were designed using Primer3Plus (Untergasser et al. 2007). Amplification products were confirmed via electrophoresis on $7 \%$ denaturing silver-stained polyacrylamide gels (Creste et al. 2001). Allele scoring was carried out using the standard 10 bp DNA Ladder (Invitrogen). We tested for scoring errors resulting from stuttering or large allele dropout and the presence of null alleles in loci using the Micro-Chequer 2.2.3 program (van Oosterhout et al. 2004). Mendelian inheritance and pairwise linkage of loci were not tested, since open-pollinated seeds from known seed trees are required for these analyses (Gillet \& Hattemer 1989) and the trees did not present fruits during the field work.

\section{Data analysis}

Genetic diversity was determined based on average number of alleles per locus $(A)$, observed heterozygosity $\left(H_{0}\right)$, and expected heterozygosity $\left(H_{e}\right)$ at Hardy-Weinberg equilibrium for each locus and as an average across all loci. To establish whether the fixation index $(F)$ and linkage disequilibrium between pairwise loci are significantly different from zero, we used Monte Carlo permutations of alleles between individuals and Bonferroni correction (95\% $\alpha=0.05$ ). All estimations were performed using the FSTAT program (Goudet 2002).

Intrapopulation SGS was assessed using the coancestry coefficient estimate between pairwise individuals $\left(\theta_{i j}\right)$, as proposed by Nason and described in Loiselle et al. (1995). For visualization of SGS, mean values were calculated for pairs of individuals within ten distance classes with the same pairwise number of individuals (495). To test whether the mean values were significantly different from zero, a confidence interval of $95 \%$ probability was calculated for each value in each distance class using 1,000 Monte Carlo permutations of individuals between distance classes. The confidence interval was used to construct the correlogram. All analyses were carried out using 
Table 1 Microsatellite primers developed for Esenbeckia leiocarpa

\begin{tabular}{|c|c|c|c|c|c|}
\hline Locus & Primer sequences & Repeat motif & $\begin{array}{l}\text { Size } \\
\text { range } \\
\text { (bp) }\end{array}$ & $\begin{array}{l}\mathrm{Ta} \\
\left({ }^{\circ} \mathrm{C}\right)\end{array}$ & $\begin{array}{l}\text { GenBank } \\
\text { accession } \\
\text { no. }\end{array}$ \\
\hline EL01 & $\begin{array}{l}\text { F: GAATGGCTGATATTGATGATGC } \\
\text { R: GATGATGCTTTCCCGTCTATG }\end{array}$ & $(\mathrm{CA})_{5}$ & 174 & 60 & KF220760 \\
\hline EL02 & $\begin{array}{l}\text { F: ATGAGGCCACTTCGCTAAAC } \\
\text { R: CACCTTTTGAGTGTCTTTGAGC }\end{array}$ & $(\mathrm{CA})_{5}$ & 210 & 56 & KF220761 \\
\hline EL03 & $\begin{array}{l}\text { F: AGCCCTTTTTCCATGTTAGC } \\
\text { R: CCTTGGACACTACTCATCATCC }\end{array}$ & $\begin{array}{l}(\mathrm{AGA})_{4} \\
/(\mathrm{GGA})_{5} \mathrm{AGG}(\mathrm{GAAA})_{7}\end{array}$ & 200-204 & 60 & KF220762 \\
\hline EL04 & $\begin{array}{l}\text { F: TCAACACTTGGTGGGCATAG } \\
\text { R: GATGGTGTGTGTGCGTATTTG }\end{array}$ & $(\mathrm{CA})_{6}$ & 246 & 60 & KF220763 \\
\hline EL05 & $\begin{array}{l}\text { F:GTGCTCGAAAATTACCCAAA } \\
\text { R:CCCTAGTTAAGGGGGTTGG }\end{array}$ & $(\mathrm{CA})_{16}$ & NA & 54 & KF220764 \\
\hline EL06 & $\begin{array}{l}\text { F: GCCCATTGTGTATGAAGCTC } \\
\text { R: TTGCGCTCATCATTTTTCAC }\end{array}$ & $(\mathrm{AATA})_{4} \mathrm{C}(\mathrm{AC})_{6} \mathrm{AT}(\mathrm{AC})_{6}$ & 160 & 56 & KF220765 \\
\hline EL07 & $\begin{array}{l}\text { F: AGAGTCTCATGCACAATAGGC } \\
\text { R: TCATATAATCAACCCCCTTTTC }\end{array}$ & $(\mathrm{AC})_{19}(\mathrm{AT})_{7}$ & 180-194 & 64 & KF220766 \\
\hline EL08 & $\begin{array}{l}\text { F: CCTTGGACACTACTCATCATCC } \\
\text { R: CATGGGTTTTAGCCCTTTTTC }\end{array}$ & $(\mathrm{TTCT})_{7} /(\mathrm{TCC})_{5} /(\mathrm{CTT})_{4}$ & $208-210$ & 60 & KF220767 \\
\hline EL10 & $\begin{array}{l}\text { F: TTCAGGAACGAAAAAGTCCAG } \\
\text { R: TGCTTTAATGGGTGTTTTGC }\end{array}$ & $(\mathrm{TAAA})_{3}$ & 230 & 56 & KF220768 \\
\hline EL11 & $\begin{array}{l}\text { F: TCACCGCAACAAAAATCATC } \\
\text { R: GGAGCGTCATCAGAATTTAGG }\end{array}$ & $(\mathrm{AC})_{8}$ & 216 & 56 & KF220769 \\
\hline EL12 & $\begin{array}{l}\text { F: CGCACAACTCACACACACC } \\
\text { R: TATGCTTCCCAAACCATGAG }\end{array}$ & $(\mathrm{AC})_{6}$ & 150 & 64 & KF220770 \\
\hline EL13 & $\begin{array}{l}\text { F: GATGGTGTGTGTGCGTATTTG } \\
\text { R: ATCAACACTTGGTGGGCATAG }\end{array}$ & $(\mathrm{GT})_{6}$ & 246 & 60 & KF220771 \\
\hline EL14 & $\begin{array}{l}\text { F: TTGCGCCTCATCATTTTTC } \\
\text { R: AGCCCATTGTGTATGAAGCTC }\end{array}$ & $(\mathrm{TG})_{8} \mathrm{TA}(\mathrm{TG})_{7}$ & 160 & 56 & KF220772 \\
\hline EL15 & $\begin{array}{l}\text { F: TTTGAGTCGCAATACACATGC } \\
\text { R: ATTCCTTGAAACCGTGAACC }\end{array}$ & $(\mathrm{AC})_{8}$ & 186 & 62 & KF220773 \\
\hline
\end{tabular}

Note. $\mathrm{NA}=$ No amplification; $\mathrm{Ta}\left({ }^{\circ} \mathrm{C}\right)=$ Annealing temperature

Spagedi 1.3 (Hardy \& Vekemans 2002).

Group coancestry within populations was estimated as the average coancestry coefficient between all pairwise individuals $(\Theta)$ using the Nason coancestry estimator (Loiselle et al., 1995) and Spagedi 1.3:

$$
\Theta=\left[0.5 N(1+F)+\sum_{i=1}^{n} \sum_{i \neq j}^{n} \theta_{i j}\right] / N^{2}
$$

(Lindgren et al. 1997), for a sample of $N$ individuals. This included the coancestry between individuals $i$ and $j\left(\theta_{i j}\right)$ and $F$ as the cor- responding average coefficient of inbreeding. The variance effective population size was calculated as $N_{e}=0.5 / \Theta$ (Cockerham 1969). The inbreeding coefficient was inferred from the fixation index, estimated for each individual using the SPAGEDI 1.3 program. The ratio of $N_{e}$ to the census size of the population $(N)$ was calculated as $N_{e} / N$.

\section{Results}

Among the 14 loci developed, 11 were not 
useful due to the absence of polymorphisms and lack of amplification for this population (Table 1). Using the Micro-Chequer program, we found no signs of large allele dropout or stuttering in the three loci used (EL03, E107 and EL08). No evidence of null alleles was detected in loci EL03 and E107. Null alleles may be present in EL08, in view of observed excess of homozygous for most allele size classes. However, this excess of homozygous may also be attributable to inbreeding. Thus, none of the loci were excluded from the analyses.

After Bonferroni correction, genotype linkage analysis was detected between loci EL03 and EL07. The number of alleles $(A)$ ranged among loci from 3 to 4 , with an average of 3.3 (Table 2). The observed heterozygosity $\left(H_{0}\right)$ ranged from 0.072 to 0.404 (average of 0.336 ) and expected heterozygosity $\left(H_{e}\right)$ from 0.131 to 0.395 (average of 0.298 ). The fixation index range was from -0.022 to 0.449 , with the average being significantly greater than zero $(F=$ $0.112, P<0.05)$, suggestive of inbreeding.

In a typical isolation by distance model, the pairwise coefficient of coancestry decreases with increased distance among trees (Figure 2). Significant SGS was evident up to $7 \mathrm{~m}$ and from 31 to $38 \mathrm{~m}$, suggesting that trees within these distance classes are related.

The estimated group coancestry was 0.03792 , resulting in an effective population size $\left(N_{e}\right)$ of 13.2. This result is significantly lower than the number of individuals sampled within the population (100). The low ratio between the effective population size and census $\left(\mathrm{N}_{\mathrm{e}} / \mathrm{N}=\right.$ 0.13 ) indicates that among the 100 adult trees sampled, approximately 14 individuals were unrelated and not inbred.

\section{Discussion}

This is the first study to apply specific microsatellite loci for analysis of genetic diversity, inbreeding, SGS and effective size of a population of the Neotropical tree species $E$. leiocarpa. Among the 14 markers developed, three were used based on evidence of variability. Genotypic disequilibrium was detected between two of the identified loci. Genotypic disequilibrium between pairwise loci in plants is caused by selfing, mating among relatives, bottleneck and founder effects (Hartl \& Clark 1989, Tambarussi et al. 2013). As the species is self-incompatible, the causes of genotypic disequilibrium in the present population are likely to be the result of mating among relatives, overlapping generations and founder effect due to forest fragmentation, resulting in genetic drift. However, other populations of the species may not present the observed genotypic disequilibrium. Our results support the utility of these three loci for genetic diversity, genetic structure, mating system, gene flow and parentage analyses for this species. Furthermore, these microsatellite loci may be applicable to studies on other species of the genus Esenbeckia. A genus of the Rutaceae family, Esenbeckia, includes 29 species native to the Americas that present the highest inter-species diversity in South America (Everett 1981). The extensive use of microsatellite loci to study plant spe-

Table 2 Genetic diversity parameters in 100 adult trees of Esenbeckia leiocarpa from the Ibicatu population, São Paulo State, Brazil

\begin{tabular}{llllll}
\hline Locus & $N$ & $A$ & $H_{0}$ & $H_{e}$ & $F$ \\
\hline EL03 & 95 & 3 & 0.354 & 0.368 & 0.038 \\
EL07 & 91 & 4 & 0.404 & 0.131 & $0.449^{*}$ \\
EL08 & 96 & 3 & 0.072 & 0.395 & -0.022 \\
Mean & & 3.3 & 0.336 & 0.298 & $0.112^{*}$ \\
\hline
\end{tabular}

Note. $N$ is the sample size, $A$ the average number of alleles per locus, $H_{0}$ the observed heterozygosity, $H_{e}$ the expected heterozygosity, and $F$ the fixation index. ${ }^{*} P<0.05$. 


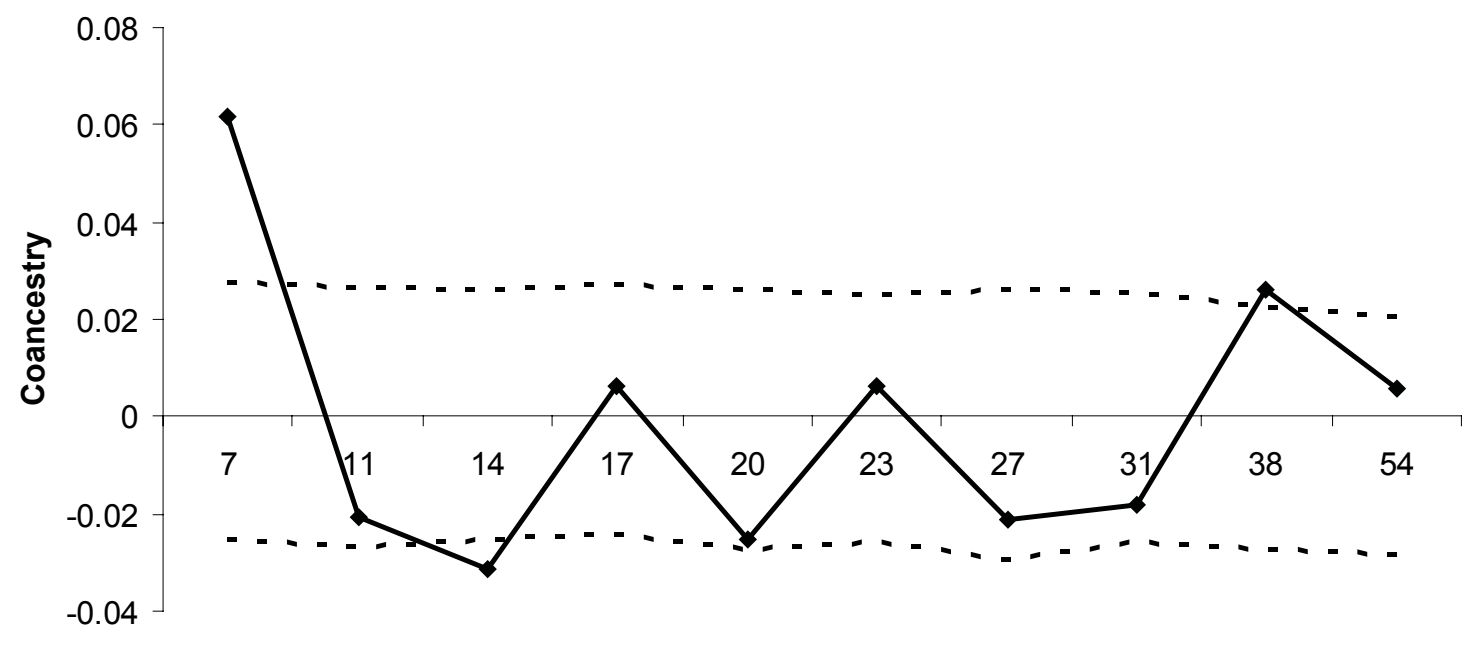

Distance (m)

Figure 2 Correlogram of average coancestry coefficients $\left(\theta_{i j}\right)$ of pairwise Esenbeckia leiocarpa trees. The solid line represents the average $\theta_{i j}$ value and dashed lines represent the twotailed $95 \%$ confidence interval of the average $\theta_{i j}$ distribution calculated by 1,000 permutations of spatial distance among pairwise adult trees

cies is facilitated by the fact that loci are often transferable across species. Several studies to date have demonstrated the transferability of microsatellite loci from one species to others of the same genus and even species of other genera (Kuleung et al. 2004, Ekue et al. 2009, Sudheer et al. 2011, Rai et al. 2013).

Genetic diversity in terms of the number of alleles and heterozygosity was low in the population (Table 2). Low polymorphism may be due to genetic drift in the population as well as the behavior of the pollinator (flies generally have a short flight range), leading to random fixation of alleles in the population. Inbreeding within the population was additionally detected. Moreover, the results of this study may reflect the landscape surrounding the target population, as it is bordered by various types of monoculture, which may lead to isolation by restricting gene flow between populations.

Significant SGS was found up to $7 \mathrm{~m}$ and from 31 to $38 \mathrm{~m}$, suggesting that individuals within this distance are more likely to be related. SGS in plants is caused by short-distance dispersal of seeds (close to the mother tree) and pollen (Sebbenn et al. 2011, Silva et al.
2011). The seeds of E. leiocarpa are dispersed by autochory, generally up to a distance of 5 $\mathrm{m}$, and flies are the main pollinator (Seoane et al. 2000). Thus, seed and pollen dispersal in particular account for significant SGS up to $7 \mathrm{~m}$. Significant SGS has also been reported for many other tropical tree species (Degen et al. 2004, Hardy et al. 2006, Bittencourt \& Sebbenn 2007, Gaino et al. 2010, Sebbenn et al. 2011, Silva et al. 2011). SGS within populations promotes the occurrence of mating among relatives, which could explain the significant inbreeding detected in the studied population (Table 2). Earlier analysis of the mating system in this population by Seoane et al. (2001) revealed a significant rate of mating among relatives $\left(t_{m}-t_{s}=0.061\right)$, consistent with our results. However, further studies on the occurrence of inbreeding are necessary because the species has been described as self-incompatible (Faegri \& Pijl 1966), and consequently, mating among relatives within the population was not expected.

The effective population size estimate $\left(N_{e}\right)$ was very low (13.2), resulting in a low ratio between the effective population size and cen- 
sus size $\left(N_{e} / N=0.15\right)$. The observed low $N_{e} / N$ ratio was attributed to the presence of inbred and related individuals in the population, as detected with fixation index and SGS analyses, ultimately leading to higher frequencies of identical-by-descent alleles within and among individuals and reduced $N_{e}$.

Our results provide important information for use in developing planning strategies for in situ conservation of E. leiocarpa. Clearly, despite the high density of the studied population, high genetic diversity and effective population size are not maintained in this case. These findings highlight the necessity of introducing individuals into the population for in situ conservation. Such a measure should increase genetic diversity and effective population size, thus enhancing the evolutionary potential of the population.

\section{Conclusions}

The microsatellite loci developed for E. leiocarpa revealed low levels of polymorphism within the studied population, and may be suitable for genetic studies on other populations of the same species. The developed loci should provide valuable information for the management of fragmented populations, including breeding, conservation and environmental reforestation plans. In general, our results indicate limited gene flow due to low levels of genetic diversity, small effective population size, substantial inbreeding and SGS. Thus, estimation of the contemporary pollen and seed flow in the population using parentage analysis is important to clarify the potential impact of new alleles on its genetic structure.

\section{Acknowledgements}

This research was supported by FAPESP (2012/20790-3) and CNPq (470491/2010-8). The authors are grateful to FAPESP for finan- cial support provided to Evando Vagner Tambarussi (2010/12354-3), GF (2012/20790-3) and GMM (2010/50033-4) and CNPq for financial support to Alexandre Magno Sebbenn and Roland Vencovsky. We also thank Dr. Evelyn R. Nimmo for editing the English and the reviewers for constructive criticism of a previous version of the manuscript.

\section{References}

Aguilar R., Quesada M., Ashworth L., Yvonne Herrarias D., Lobo J., 2008. Genetic consequences of habitat fragmentation in plant populations: susceptible signals in plant traits and methodological approaches. Molecular Ecology 17: 5177-5188. DOI: 10.1111/j.1365294X.2008.03971.x.

Billotte N., Lagoda P.J.L., Risterucci A.M., Baurens F.C., 1999. Microsatellite-enriched libraries: Applied methodology for the development of SSR markers in tropical crops. Fruits 54: 277-288.

Bittencourt J.M., Sebbenn A.M., 2007. Patterns of pollen and seed dispersal in a small fragmented population of a wind pollinated Araucaria angustifolia in southern Brazil. Heredity 99: 580-591. DOI: 10.1038/ sj.hdy.6801019.

Breed M.F., Marklund M.H.K., Ottewell K.M., Gardner M.G., Harris J.B.C., Lowe A.J., 2012. Pollen diversity matters: revealing the neglected effect of pollen diversity on fitness in fragmented landscapes. Molecular Ecology 21: 5955-5968. DOI: 10.1111/mec.12056.

Breed M.F., Ottewell K.M., Gardner M.G., Marklund M.H.K., Dormonttand E.E., Lowe A.J., 2013. Mating patterns and pollinator mobility are critical traits in forest fragmentation genetics. Heredity. DOI: 10.1038/ hdy.2013.48.

Cockerham C.C., 1969. Variance of gene frequencies. Evolution 23: 72-84. DOI: 10.2307/2406485.

Chase M.R., Moller C., Kesseli R., Bawa K.S., 1996. Distant gene flow in tropical trees. Nature 383: 398-399. DOI: $10.1038 / 383398 \mathrm{a} 0$

Crestes S., Tulmann A.N., Figueira A., 2001. Detection of single sequence repeat polymorphism in denaturing polyacrylamide sequencing gels by silver staining. Plant Molecular Biology Reporter 19: 299-306. DOI: 10.1007/BF02772828.

Degen B., Bandou E., Caron H., 2004. Limited pollen dispersal and biparental inbreeding in Symphonia globulifera in French Guiana. Heredity 93: 585-591. DOI: 10.1038/sj.hdy.6800560.

Doyle J.J., Doyle J.L., 1987. A rapid DNA isolation procedure for small quantities of fresh leaf tissue. Phytochemistry 19: 11-15.

Ekue M.R.M., Gailing O., Finkeldey R., 2009. Transfer- 
ability of simple sequence repeat (SSR) markers developed in Litchi chinensis to Blighia sapida (Sapindaceae). Plant Molecular Biology Report 27: 570-574. DOI: 10.1007/s11105-009-0115-2.

Everett T.H., 1981. The New York Botanical Garden Illustrated Encyclopedia of Horticulture 4. Courier Corporation. p. 1268. ISBN 978-0-8240-7234-6.

Faegri K., L. Pijl, 1966. The principles of pollination ecology. Oxford, Pergamon. 2:29.

Gaino A.P.S.C., Silva A.M., Moraes M.A., Alves P.F., Moraes M.L.T., Freitas M.L.M., Sebbenn A.M., 2010. Understanding the effects of isolation on seed and pollen flow, spatial genetic structure and effective population size of the dioecious tropical tree Myracrodruon urundeuva. Conservation Genetics 11: 1631-1643. DOI: 10.1007/s10592-010-0046-3.

Gillet E., Hattemer H.H., 1989. Genetic analysis of isoenzyme phenotypes using single tree progenies. Heredity 63, 135-141.DOI: 10.1038/hdy.1989.84.

Goudet J., 2002. Fstat (Version 2.9.3.2.): a computer program to calculate F-statistics. Journal of Heredity 86 : 485-486.

Hardy O., Vekemans X., 2002. SPAGeDI: a versatile computer program to analyze spatial genetic structure at the individual or population levels. Molecular Ecology Notes 2: 618-620.DOI: 10.1046/j.1471-8286.2002.00305.x.

Hardy O.J., Maggia L., Bandou E., Breyne P., Caron J., Chevallier M.H., Doligez A., Dutech C., Kremer A., Latouche-Hallé C., Troispoux V., Veron V., Degen B., 2006. Fine-scale genetic structure and gene dispersal inferences in 10 neotropical tree species. Molecular Ecology 15: 559-571. DOI: 10.1111/j.1365294X.2005.02785.x

Hartl,D.L. Clark, A.G., 1989. Principles of Population Genetics. 2 ed. Sinauer Associates, Sunderland, Massachusetts. Chapter 1.

Köppen W., 1948. Climatologia: con un estudio de los climas de la tierra. Fondo de Cultura Econômica. México. $479 \mathrm{p}$

Kalia R.K., Rai M.K., Kalia S., Singh R., Dhawan A.K., 2011. Microsatellites markers: an overview of the recent progress in plants. Euphytica 177: 309-334.DOI: 10.1007/s10681-010-0286-9.

Kuleung C., Baenziger P.S., Dweikat I., 2004. Transferability of SSR markers among wheat, rye, and triticale. Theoretical Applied Genetic 108: 1147-1150. DOI: 10.1007/s00122-003-1532-5.

Lindgren D., Luigi D.G., Jefferson P.A., 1997. Status number for measuring genetic diversity. Forest Genetics 4: 69-76.

Loiselle B.A., Sork V.L., Nason J., Graham C., 1995. Spatial genetic structure of a tropical understory shrub, Psychotria officinalis (Rubiaceae). American Journal of Botany 82: 1420-1425. DOI: 10.2307/2445869.

Lowe A.J., Boshier D., Ward M., Bacles C.F.E., Navarro C., 2005. Genetic resource impacts of habitat loss and degradation; reconciling empirical evidence and predicted theory for Neotropical trees. Heredity 95: 255-
273. DOI: $10.1038 /$ sj.hdy.6800725.

Nakatsu T., Johns T., Kubo L., Milton K., Sakai M., Chatani K., Saito K., Yamagiwa Y., Kamikawa T., 1990. Isolation, structure, and synthesis of novel 4-quinolinone alkaloids from Esenbeckia leiocarpa. Journal of Natural Products 53: 1508-1513. DOI: 10.1021/np50072a017.

Novaes W., 2001. Dilemas do desenvolvimento agrário. Estudos avançados 15: 51-60. DOI:10.1590/S010340142001000300006.

Rai M.K., Phulwaria M., Shekhawat N.S., 2013. Transferability of simple sequence repeat (SSR) markers developed in guava (Psidium guajava L.) to four Myrtaceae species. Molecular Biology Report 40: 5067-5071. DOI: 10.1007/s11033-013-2608-1.

Rajora O.P., Mosseler A., 2001. Challenges and opportunities for conservation of forest genetic resources. Euphytica 118: 197-212. DOI: 10.1023/A:1004150525384.

Ribeiro M.C., Metzger J.P., Martensen A.C., Ponzoni F.J., Hirato M.M., 2009. The Brazilian Atlantic Forest: How much is left, and how is the remaining forest distributed? Implications for conservation. Biological Conservation 142: 1141-1153. DOI: 10.1016/j.biocon.2009.02.021.

Selkoe K.A., Toonen R.J., 2006. Microsatellites for ecologists: a practical guide to using and evaluating microsatellite markers. Ecology Letters 9: 615-629. DOI: 10.1111/j.1461-0248.2006.00889.x.

Sebbenn A., 2011. Effects of forest fragmentation on the effective and realized gene flow of Neotropical tree species: implications for genetic conservation. BMC Proceedings $5: 6$.

Sebbenn A.M., Carvalho A.C.M., Freitas M.L.M., Moraes S.M.B., Gaino A.P.S.C., Silva J.M., Jolivet C., Moraes M.L.T., 2011. Low levels of realized seed and pollen gene flow and strong spatial genetic structure in a small, isolated and fragmented population of the tropical tree Copaifera langsdorffii Desf. Heredity 106: 134-145. DOI: 10.1038/hdy.2010.33.

Seoane C.E.S., Kageyama P.Y., Sebbenn A.M., 2000. Efeitos da fragmentação florestal na estrutura genética de populações de Esenbeckia leiocarpa Engl. (Guarantã). Scientia Florestalis 57: 123-139.

Seoane C.E.S., Sebbenn A.M., Kageyama P.Y., 2001. Sistema de reprodução em populações de Esenbeckia leiocarpa Engl. Revista do Instituto Florestal 13: 19-26.

Silva C.R.S., Albuquerque P.S.B., Ervedosa F.R., Mota J.W.S., Figueira A., Sebbenn A.M., 2011. Understanding the genetic diversity, spatial genetic structure and mating system at the hierarchical levels of fruits and individuals of a continuous Theobroma cacao population from the Brazilian Amazon. Heredity 106: 973-985. DOI: $10.1038 /$ hdy.2010.145.

Sousa F.M., Gandolf S., Perez S.C.J.C.A., Rodrigues R.R., 2010. Allelopathic potential of bark and leaves of Esenbeckia leiocarpa Engl. (Rutaceae). Acta Botanica Brasilica 24: 169-174. DOI: 10.1590/S010233062010000100016.

Sudheer P.D.V.N., Mastan S.G., Rahman H., Ravi P.C., Singh S., Reddy M.P., 2011. Cross species amplification 
ability of novel microsatellites isolated from Jatropha curcas and genetic relationship with sister taxa. Molecular Biology Report 38: 1383-1388. DOI: 10.1007/ s11033-010-0241-9.

Tambarussi E.V., Vencovsky R., Freitas M.L.M., Sebbenn A.M., 2013. Mendelian inheritance, genetic linkage and genotypic disequilibrium at nine microsatellite loci of Cariniana legalis (Mart.) O. Kuntze. Genetics and Molecular Research 12: 5442-5457. DOI: 10.4238/2013. November.11.6.

Untergasser A., Nijveen H., Rao X., Bisseling T., Geurts R., Leunissen J.A.M., 2007. Primer3Plus, an enhanced web interface to Primer3. Nucleic Acids Research 35 (Supplement 2): W71-W74. DOI: 10.1093/nar/gkm306. van Oosterhout C., Hutchinson W.F., Wills D.P.M., Shipley P., 2004. Micro-Checker: software for identifying and correcting genotyping errors in microsatellite data. Molecular Ecology Notes 4: 535-538. DOI: 10.1111/j.14718286.2004.00684.x.

White G.M., Boshier D.H., Powell W., 2002. Increased pollen flow counteracts fragmentation in a tropical dry forest: an example from Swietenia humilis Zuccarini. Proceedings of the National Academy of Sciences of the United States of America 99: 2038-2042. DOI: 10.1073/ pnas.042649999.

White G., Powell W., 1997. Cross-species amplification of SSR loci in the Meliaceae family Molecular Ecology 6: 1158-1197. DOI: 10.1046/j.1365-294X.1997.00297.x. 